\title{
Theology and culture in dialogue towards harmonious multi-religious and multi-cultural South Africa
}

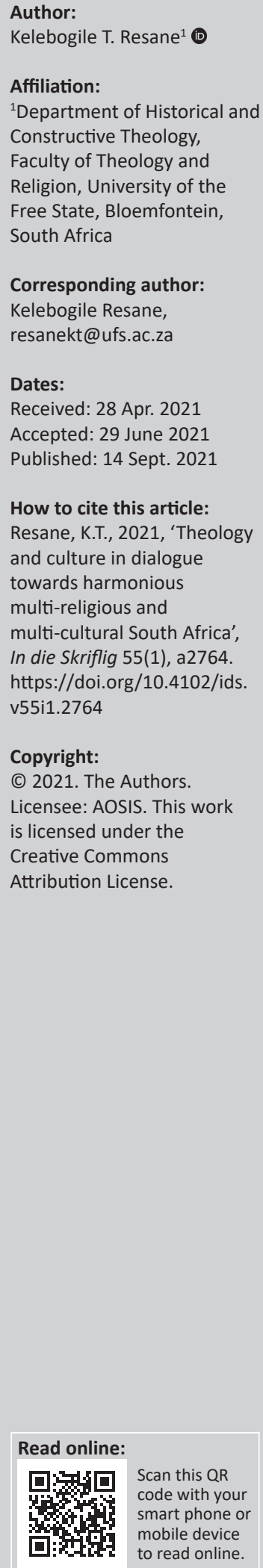

South Africa is the country of many cultures and many religions. This diversity had not created or led to significant internal strife, especially after 1994 when South Africa entered the era of democracy from the shackles of colonialism and apartheid. The previous regimes marginalised cultures as tools of unity, but preferred to use them as tools of separation, segregation, and isolation. This context calls for some dialogue between theology and cultures within South African multi-cultural and multi-religious context. Social divisions perpetuate discrimination based on culture and religion. The scope of this article is to demonstrate that when theology and culture have a dialogue with each other, an understanding of each other is heightened and harmony becomes inevitable. Through literature on history, sociology, theology, and current events, the hypothesis was made that there is a gap between culture and theology. This has created divisions in societies. Conclusions are based on theological findings that when dialogue is used, people of different cultures and religions come to understand each other. Dialogue is a biblical and theological tool to unite diverse people. It brings mutual understanding and promote cooperation and coexistence. South Africa can be a united diversified society living in peace if dialogue is given a chance. As much as there can be understanding and acceptance of people of other cultures and religions, there can be some resistance due to the historical legacy of separateness and societal isolation. Openness to others and dialoguing with them, however, breaks down walls of hostility.

Contribution: This article demonstrates the importance of theo-cultural interaction within a multi-cultural and multi-religious society. It points out the importance of the theology of dialogue engaging culture and theology to build a harmonious coexistence in a diverse society such as South Africa.

Keywords: culture; theology; dialogue; religion; race; segregation.

\section{Introduction}

One hardly hears, sees, reads or experiences tribal, ethnic, religious or class conflicts in South Africa. There are no observable cultural wars in post-apartheid South Africa. In the past there were recorded incidences between black and white people, Zulus and Xhosas, and numerous inter-tribal clashes, especially in the now Gauteng Province and KwaZuluNatal, which are convergent points of groups of people from all over the country and beyond. In the late 1980s many people had been slain in the townships surrounding Johannesburg, 'fighting that frequently has had distinct tribal overtones' (Chicago Tribune, 10 September 1990). At the dawn of democracy, the early nineties witnessed in KwaZulu-Natal the impact of ethnicity in the outbreak of widespread political conflict and death between the multi-ethnic African National Congress (ANC) and the Zulu-inspired Inkatha Freedom Party (IFP)' (Le Roux 2011:23). The list will be too long to list the inter- and intra-tribal or ethnic conflicts in South Africa. This article is not focusing on whether there are conflicts or not in South Africa. The fact remains that racism, tribalism, and all the prejudices one can think of are subliminal factors. Of course, inter-tribal marriages, cooperation, and consortia take place between or across the racial, tribal, and religious lines. Subliminally, one picks up some deindividuation, racial or tribal overtones in the casual and informal interactions. The minority religions, especially Islam and Judaism, are negatively referred to in some derogatory ways such as terrorism and bigotry, while African traditionalists are viewed as barbaric. Hence the need for a theology of dialogue to intervene as a measure of bringing harmony into the situation. This is the focus of this article.

\section{Historical reflection}

South Africa is a country of diversity - cultural, religious, ethnic, racial, economic and otherwise. During the colonial and apartheid eras, it was the country that was Christian with Calvinistic 
inclinations. The first Dutch settlers in 1652 are believed to be of Calvinist convictions from the Dutch Reformed Church and were later strengthened by the arrival of the French Huguenot settlers around 1820. They built a Calvinistic society that left some indelible marks on South African Christian heritage. Calvinism was an important element which connected and interpreted the sacrum [sacred] and profanum [profane] societally, therefore making religion a basic social phenomenon that fills a basic social need (Dobšová 2009:306). Since the settlers did not enter a religiously empty terrain, and that consequent to their settlement, different other missionary societies arrived, a new multi-religious and multi-cultural population was developing in the Cape. This new shape developed to an extent that one can boldly say that the 'South African society is characterised by religious diversity as well as by the fact that strong religious convictions generally prevail' (Lubbe in Kritzinger 2002:66).

The notion of religion as a social phenomenon was enhanced by Afrikaner nationalism that evolved from the 1830s to the 1940s. This ideology is highlighted by some mythical conception, captured by Dubow (1992:218) that: Afrikaners were created as a nation by God. That meant:

- what God created, humans cannot divide - unity of the nation;

- humans cannot put together what God has divided, higher unity is possible only in Christ and has only a spiritual character - there is no equality.

This became an ingress through which Protestant Christianity prevailed and dominated South African Christian landscape, superseding the cultural diversity existent in indigenous populations. Every sphere of life such as education, industries, and politics became government tools of, or for Christian promotion and influence. The school curricula were Christian based, and the Bible was a dompas (document designed to segregate the population and control human migration) for opening opportunities for employment, geographical settlement, marital choice, and educational accessibility. Worse still, as Dobšová (2009) verbalises:

Theologians from the pre-apartheid era in South Africa used the Bible and Christian doctrines for legitimising oppression and supporting their own supremacy. (p. 322)

These theologians believed that ethnic differences are ordained by God, therefore, should be hallowed not only on theological grounds, but also should be accorded some concrete structural expression (Thomas 2002:xvi). This created a space or legitimate reasons for theology and indigenous cultures to move apart from each other to accord a new emerging Eurocentric Christian culture, as a cultural stream or norm. This evolved into African Christian culture which started to question some equations of Western civilisations with Christianity. For instance, the emergence of African Independent Churches and Black Theology in South Africa was exacerbated by this situation which led to conflicts and clashes. The interreligious landscape is hugely affected as Clooney (2010) points out:

Colonialism both enabled and disfigured the new interreligious encounters, while Church politics and doctrinal constraints matched by parallel forces operative in the cultures and religions to which Christianity came - shaped what the unprecedented encounters might mean. (p. 25)

Inevitably, this led to proliferations instead of cordiality where the Christian community should integrate unitedly in diversities. The social transformation in the post-apartheid South Africa can be framed philosophically as an attempt to locate one's identity by way of a set of habits and practices, labeled as African. Alternatively, one could go the continental way of claiming the 'African-ness' found in or possibly reshaped by myths and other traditional narratives. This is another way of seeking African authenticity. Along the same lines, a second move was made, which is to try and find the genuine way to build up auto-determination in ideologies such as Marxism and Pan-Africanism. As could be expected, this created a huge African self-identity crisis, as Africans opted for either remaining resistantly within their roots, or going through decultural processes, becoming Africans with a Eurocentric lifestyle, interspersed with Christian principles.

\section{South African culture(s) and religions}

South Africa is a melting pot of cultures. It is a country of many cultures, languages and religions. Anthropologically, South Africa is composed of many diverse cultures and religions. After 1994, she continued to be a religious state dominated by various branches of Christianity (Protestantism, Catholicism and the minority, of Orthodox faith). The other religions include African Traditional Religions, Hinduism, Islam, and African Zionism, Bahai faith and Judaism. According to the 2011 population census, $80 \%$ of the citizens subscribe to Christianity. Despite this multi-religious composition, South Africa continues to be a secular state with a Constitution that guarantees freedom of religion. Even the minority religions such as Islam and Hinduism 'play a much greater role in political, economic and cultural institutions' (Crafford in Meiring 1996:220). Despite this demographic reflection, ' $[t]$ o a large extent we are still isolated and virtually strangers to each other' (Lubbe in Kritzinger 2002:67), although now many Christians, for the first time in their life, are encountering their neighbours and colleagues of different religious persuasions.

South Africans 'are becoming increasingly aware of the multi-religious context in which they live' (Crafford in Meiring 1996:220). Despite this scenario, the consensus is that 'our world is a torn and divided one, reflecting dehumanising and egregious social and economic inequalities' (Butkus \& Kolmes 2011:12). Attempts were and still are made to normalise or reverse the legacy of segregation inherited from colonialism and apartheid. For instance, in 1996 Archbishop Desmond Tutu (in South African History Online 2020[2016]:1) of the Anglican Church, coined the cultural reference famously known as: 
Rainbow Nation to encapsulate the unity of multi-culturalism and the coming-together of people of many different races, in a country once identified with the strict division of white and black [people].

This cultural reference captured some politicians, especially the then President Nelson Mandela, who Manzo (1996) quotes as saying:

Each of us is as intimately attached to the soil of this beautiful country as are the famous jacaranda trees of Pretoria and the mimosa trees of the bushveld - a rainbow nation at peace with itself and the world. (p. 71)

The diverse tribal and ethnic groups in South Africa are not linguistically or culturally homogenous. Diversity is observed in their cultural practices, religious processes, languages, and social structures. This cultural diversity rationalised and necessitated the officialisation of 11 languages as official languages. These languages are (not in any order of importance) Afrikaans, English, Setswana, Northern Sesotho (Sepedi), Southern Sesotho, Xitsonga, siSwati, Tshivenda, isiNdebele, isiZulu, and isiXhosa. There are, of course, minor indigenous groups such as the Khoisan groups (Khoi and San), who are in a very minute minority and are believed to be the original inhabitants of the southern tip of the continent. All these indigenous groups, together with their European descendants, continue to observe and express their cultural practices. The gaps between these practices are still anthropologically visible in all spheres of society. Kusmierz and Cochrane (in Lienemann-Perrin \& Cochrane 2013:57) are correct in saying that 'beside the economic cleavages, the chasms between the different ethnic groups also contribute to a strongly fragmented population structure'. Cochrane (2000:445) further alludes to the fact that diversity and plurality, after a long time, have come much more strongly to the fore with social and political reconstruction in the postapartheid South Africa. There are some thick lines between these cultural expressions. Although indigenous languages are still widely recognised and spoken, English has become a recognised business and public communication language. It is obvious that the colonial language has taken precedence over the indigenous languages.

South Africa is a multi-cultural and multi-religious society. This proliferation is exacerbated by migration and immigration, mass and social media, and refugee factors due to socio-civic instabilities in other nations. As per languages stated above, the various racial, tribal, and ethnic groups include the Nguni (amaZulu, amaXhosa, amaNdebele and amaSwati people), the Sotho (Basotho, Bapedi and Batswana people), VaTsonga, VhaVenda, Afrikaners, English, Coloured people, Indian people, and those who have immigrated to South Africa from the rest of Africa, Europe and Asia and who maintain a strong cultural identity (Government Communication and Information System [GCIS] 2012). People converge into the cities, towns, villages, townships, and informal settlements, thus bringing into close proximity different religions and cultures.
Unfortunately, in the past the colonialists and the apartheid architects used the diversity to either promote or justify exclusion, not unity and inclusion, while in the present the same status quo is promoted through xenophobia, deindividuation, and dehumanisation. The missionary era theology has the historical and significant 'legacy of developing the idea of civil society' (Mathwig \& Lienemann in Lienemann-Perrin \& Cochrane 2013:37), based on separate ethnic or tribal entities. The South African church history is a 'history of fragmentation and separationism - rather than a progressively restorative synthesis' (Delotavo 2012:167). Indigenous Africans were racially disaggregated into tribes in order to enhance and maintain apartheid policies (Valji 2003:13). Tribal identities were bantustanised as a way of making these people foreigners in their own land (greater South Africa), as each tribal group was designated a territory, popularly known as Bantustans, where they could conglomerate and aspire to tribal cultural values. The inevitable scenario as expressed by Gibson and Gouws (2003), is the following:

South Africa is one of the most polyglot countries in the world; race is certainly important in South Africa, but so too are language, ethnicity, class, and ideology. South Africa has no hope of ever becoming homogenous, the South African 'pot' will never 'melt'. (p. 5)

Historically due to segregationist policies, the religions lived apart from each other, now they live together in the same neighbourhood, calling Christians into dialogue with them for better understanding of and respect for each other. The call for dialogue will contribute towards mutual understanding of each other's worldviews. South Africans in their multi-cultural and multi-religious composition, like all people the world over, develop specific worldviews. These views are enhanced by diversities and multiplicities of national compositions. By worldview is meant the way how people view and identify their world. Slack (ION/LCWE 2010:73) asserts that worldview is 'a composite of the core beliefs, values, cultural views, and practical lifestyle habits that characterise a person within a specific ethnolinguistic people group'. It is the worldviews that sometimes develop stereotypes, prejudices, and generalisations about people. Examples can be cited of predominantly Christian neighbourhoods resisting the erection of a mosque in their proximity. They claim noise pollution by call for prayer every four hours from the minaret. In some big cities, the traditional hourly church bells had to cease operating due to solidarity claims to environmental sanctity. Some residents in previously and predominantly suburbs of our cities abhor their African neighbours' slaughtering of animals for ritual purposes, claiming that this is cruelty to animals. During the Muslim Ramadan, both white and black Christians are uneasy hearing the bleating goats slaughtered after sunset. Further, predominantly Christian residents are uncomfortable with crackers during the Hindu Diwali celebrations. These attitudes and sentiments hamper the eschatological national journey towards harmony in the multi-cultural and multi-religious people context. Religions existed separately in the past and 
were practised in their racially and religiously segregated territories, including their community and learning centres.

\section{Theology and culture in dialogue}

The famous Sermon on the Mars Hill in the Book of Acts (Ac 17:22-31) is a picture of theology dialoguing with culture in order to bring the message of the gospel across. This hill in Athens was known as the Hill of Ares, or the Areopagus (Ac 17:19, 22), and the Romans called it Mars Hill. It served as the meeting place for the Areopagus Court, the highest court in Greece for civil, criminal, and religious matters. Even under Roman rule in the time of the New Testament, Mars Hill remained an important meeting place where philosophy, religion, and law were discussed. So, it was a rendezvous for dialogue. It was 'an intellectual center and a religio-cultural center' (Wagner 1994:106), the epicentre of superstition of Greek culture that depressed Paul (Robertson 1931:278).

Here the Apostle did a gospel presentation during the second missionary journey, addressing the religious idolatry by using the teaching method of 'From known to unknown', with reference to the altar's inscription of TO THE UNKNOWN GOD. This inscription became a starting point in dialogue, from cultural knowledge to theological understanding. Marshall (1998:286) points out that 'He eagerly seized on this inscription as a way of introducing his own proclamation of the unknown God'. So, he reasoned (Ac 17:17), which is dieelegeto men oun. It was from the root dialegō, where we get the English word, dialogue. He engaged in conversation with the people around. There was exchange, questions and answers. He dialogued with them from the Scriptures. This is a classic example of gospel presentation, beginning where the audience was (culture), and the process became apologetics in action.

This was a multi-cultural and multi-religious audience, because the city was 'given over to idols' (Ac 17:16) and he started dialogue in the synagogue with 'the Jews and with the Gentile worshippers' (Ac 17:17) and moving into the public spaces - the melting pot of cultures - he continued his presentations daily. Daily dialogue opened more opportunities, especially with the philosophers known as Epicureans and Stoics (Ac 17:18-20). Their invitation to Paul was due to curiosity, as they 'brought him to the Areopagus' to hear more from him (Ac 17:19-20). These were the two philosophies at loggerheads with each other, the common belief of both groups is that they were philosophically theological and cultural. Philosophy and religion were their subject of debate. For instance, the Epicureans believed in a God who was not attached to human affairs, therefore humans must aspire to pleasure in life. 'They stressed the importance of pleasure and tranquillity' (Marshall 1998:284), hence that 'we should eat and drink and be merry to get all the pleasure from life possible' (Wagner 1994:112). Barnes reinforces their belief that pleasure was summum bonum - it was a chief good, but this pleasure was not about sensualities, but rational pleasure that is properly regulated and governed (1979:257). On the other hand, the Stoics were very theocentric. That means, for them God was the world's soul, and the goal of life was human supremacy over everything, showing no emotional response to either pain or pleasure. Humans 'should submit patiently to whatever fate might bring through self-control, not pleasure-seeking' (Wagner 1994:112). The passions and affections are to be suppressed and restrained. Self-righteousness was the highest virtue (Barnes 1979:257). They taught self-mastery and hardness with austerity governed by pantheism (Robertson 1931:280).

Paul's meticulous way of engaging dialogue in this narrative, teaches us that through dialogue between theology and culture, theological convictions arise whereby people make some informed decisions to believe or to reject him. 'His goal was to deliver a speech that was theologically impeccable and yet skilfully contextualised to the culture of Greek philosophers' (Wagner 1994:115). Of course, some may reject God, but most notable and crucial is that some become open-minded and have the desire to hear more. What happened on Mars Hill is important because of the many lessons that can be learned, not only from how Paul presented the gospel and a biblical worldview, but also in the varied responses he received. Some of those there that day believed and were saved, others mocked Paul and rejected his message, and still others were open-minded and desired to hear more. We can only hope that those who were open-minded were later convinced of the truth, repented and believed. Theo-cultural interactions create a thirst to learn more about God.

Regardless of the historical stigma of theology that served the purposes of hatred, segregation, exclusion, and violence in South Africa, Christianity remains a religion of love and forgiveness. In the post-apartheid South Africa, dialogue should be a means towards societal harmony, peace and stability. Moltmann (2003) correctly points out that:

If we do not talk to each other, someday we will be shooting at each other ... Dialogue is the only method of making and keeping peace, and only a dialogical church can be a church of peace. (p. 12)

Theology is not a back-seat science, or a conference process observer. It is a speaking science that should be audible and oral enough to be in partnership with the cultural realists such as anthropologists, sociologists, psychologists and traditionalists. 'Theological silence in times of crises is not justified' (Resane 2018:11). Theology is developed to address specific cultural, social, political, and economic issues facing the various societies in which such theologies are shaped. In other words, 'the task of theology is to give a Christian response to culturally-rooted concerns. This means theology must take culture and context seriously' (NkansahObrempong 2007:1). It 'should strive to have dialogue everywhere, especially in societies that are mixed religiously, ideologically, racially, and culturally' (Moltmann 2003:13). God-human and human-human dialogue are 'mutually necessary and interdependent' (Ratzinger 2004:94), 'seeking common ground and gaining understanding about God's ways and wisdom in others' (Richie 2011:80). 
Currently South African cultures and theology are strange bedfellows. 'Culture in South Africa is itself diverse and contradictory, thus requiring different responses even within the same historical context' (De Gruchy in Regan \& Torrance 1993:131-132). For instance, it is a long way for Christian theology to understand the African spirituality of a sangoma, who is also a full and a dedicated member of the local church. Theology needs to come closer to understand a person claiming Christ as Lord and Saviour yet continues to go through cleansing ceremonies during or after a period of mourning. There is a need for theology to discover the role of the witchdoctor to protect or strengthen the Christian weddings, household's properties, and livestock. The rationale for the resurgence of these practices is the cultural renewal that comes along with national independence or democracy, when Africans embark on rediscovering themselves by attempting to unshackle themselves from the colonial or apartheid influences. They resort to embracing the ancestral veneration and mystical powers ( $\mathrm{O}^{\prime}$ Donovan 1996:255). These syncretic practices challenge theology practised on the African cultural landscape. Regardless of all these practices, Orobater (2008) claims:

Theologians need to recognise and respect the innate sense of the faith of the people. This sense allows them to see possibilities of encounter between Christian faith and African religious and cultural traditions. (p. 132)

Dialogue between theology and culture is necessitated by the ensuing syncritic practices prevalent within African Christianity. Syncretism has become synonymous with Christianity in Africa. 'Syncretism means combining the elements of many religions into one' (Kato 1975:134). However, this battle is not new, as Christianity had always been in battles to preserve its monotheism and sacredness. Think of the gnostic debates, crusaders and iconoclastic debates. One can recall in length the words of one of the great American missiologists, McGavran (1972) here:

\footnotetext{
It seems clear that the next decades, Christians again, as in the first two centuries, will fight the long battle against syncretism and religious relativism. And for the same reason - namely, that they are again in intimate contact with multitudes of non-Christian peers who believe that many paths lead to the top of the mountain. The concept of the cosmic Christ, some maintain, is a way out of the arrogance which stains the Christian when he proclaims Jesus Christ as the only way to the Father. Other Christians believe that the concept of a 'cosmic Christ operating through many religions' sacrifices truth, for if there are, in fact, many revelations, then each voices approximation of truth ... (p. 17)
}

The remaining factor is that historically South African mainstream theology had marginalised and bypassed the indigenous cultures, hence religion has become a point of conflict in a multi-cultural and multi-religious society. This is in consonant with Volf (1996:78) that 'we exclude because we want to be at the center and be there alone, singlehandedly controlling "the land"'. Despite the scenario, theology should initiate dialogue with cultures. There is a great need for communio theologorum - a community of theologians which engages in disputes, dialogue, and 'occasionally interacts in mutual influence and enrichment' (Moltmann 2000:61). These theologians should promote the theology that becomes a mode of enquiry, engaging issues intellectually with commitment to community values, with a willingness to affirm the truths and values of the cultural group engaged. It does not come with some superior attitude, but with a humble expectation of learning from its own concepts and those of cultural realists. 'Dialogue demands mutual exchange, the equality of everybody involved' (Osredkar in Petkošsek \& Žalec 2019:137). Dialogue is an eschatological and infinite event. Participants are not the finalists in the game, but eschatological beings on the way towards reaching the goal. 'Each participant in the dialogue recognises that his/her position is not absolute, final and unmodifiable' (Jamnik in Petkošsek \& Žalec 2019:87).

Theology in the free society is a form of cultural activity. It cannot operate outside, below, beyond or beside culture. Butkus and Kolmes (2011) correctly point out that:

... theology has always been enculturated, rooted in a given culture utilising its language, symbols, and modes of thought, as well as its political and economic structures to create a theologically meaningful world. (p. 11)

Historically, 'religions were shaped by particular cultures and cultures by particular religions' (Prijatelj in Petkošsek \& Žalec 2019:169). Hence, theologising means immersion in cultures where theology needs to be active. In this context, culture is meant what Gallagher (2004) proposed:

Culture may now be said to be the whole complex of distinctive spiritual, material, intellectual and emotional features that characterize a society or social group [...]. It is through culture that man expresses himself, becomes aware of himself, recognizes his incompleteness, questions his own achievements, seeks untiringly for new means and creates works through which he transcends his limitations. (p. 160)

This definition emphasises some creative imaginations of people of a given society, such as lifestyle, life-decision, and the religious aspects of life. It is true indeed, as Kovács (in Petkošsek \& Žalec 2019:122) asserts, that 'religious faith is a culture-specific or culture-dependent phenomenon; it is the essence of the given culture'. This is when culture becomes a source for theology, what is termed contextualisation; and it informs us far beyond an apologetic work of transmitting a depositum fidei [deposit of faith] never to be tampered with. It is vital for theology to understand the appropriate articulation of a faith discourse and the cultural expressions of the time. The apostolic wisdom, as verbalised in 1 Corinthians 9:20-22 (NIV) needs to be applied:

To the Jews I became like a Jew, to win the Jews. To those under the law I became like one under the law (though I myself am not under the law), so as to win those under the law. To those not having the law I became like one not having the law (though I am not free from God's law but am under Christ's law), so as to win those not having the law. To the weak I became weak, to win the weak. I have become all things to all people so that by all possible means I might save some. 
This calls for theologians who have the capacity to articulate their convictions, without compromising their own theological convictions and stances. Moltmann (2000:18) is correct that 'we may expect Christian theologians to be capable of dialogue'. Instead of continuing with building walls of hostility, and becoming gated communities, insulating ourselves with tall concrete walls crowned with electric fences, we should avail ourselves to approach our neighbours and engage dialogically in order to understand. McLennan (2016:132) is correct that life would be brighter if people living in the community could know that 'exchanging jokes and humorous anecdotes can be a wonderful form of intercommunity dialogue'. We should weave together in the transparent space of desiring to understand and to know each other. We should adopt Moses's attitude of 'I will go over and see this strange sight - why the bush does not burn up' (Ex 3:3 NIV). Slatinek (in Petkošsek \& Žalec 2019:186) correctly captures it: 'where there are dialogues people are accepted for what they are ... Therefore, dialogue requires patience, understanding, tolerance and generosity'. Communities should become the interwoven space of dialogue and conversation with other narratives and religions (Meylahn 2012:48). Individual proximity is enhanced by dialogue. The agenda or motive is not to convert or to win over the person of the other religion to ours, but to discover 'how we can live together at peace and mutually enrich one another' (Pobee in Kroesbergen 2015:23). We enrich each other through dialogue. As Thiemann (1991:1690) asserts, 'we must seek to develop genuine communities of discourse in which people of differing and even conflicting points of view engage in critical conversation with one another'. This is the key to solidarity, harmony, and mutuality, because 'when people voluntarily come together in cooperatives, they become strong' (Moltmann 2019:53).

Dialogues are interwoven and intertwined with homology. Theologically this means listening transparently to what is said, what is binding, when to agree and disagree, and when to consent and confess. In dialogue, there is no gullibility of facts stated, but space to listen, ask for clarification, and confess when misunderstanding prevailed. Sauter (2003:29) tries to clarify that homology 'marks the point which the language of commitment arises, which cannot acknowledge any other underlying presupposition as the basic condition of understanding'. Homology directs listeners to confession, as 'to speak homologically is to stand upon what is received through God's action' (Sauter 2003:30). Dialogical partners stand together because they acknowledge their common origin. In this discussion, theology and culture's common origin is God through humanity. God created humans and humans experience life through theology and culture. The two do not invent or establish the way forward but discover it together.

Theology of dialogue ushers in the community of mutuality, where members break out of the shells of navel-gazing and self-centredness. Resane (2020:272) calls for the church to stop being parochial, involved in navel-gazing, that is, being absorbed in their own interests, excluding others. Different people all over the world are merging into one humanity, and 'different cultural traditions are melding together' (Moltmann 2019:34). This merging and melding speak of the community of mutuality as the 'one in which each member stands in a dialogical relation to other members' (Coetzee \& Roux 2000:278). This community pursues the common good more than individually chosen interests or ends. It is the African philosophy that 'the well-being of the community strongly influences the well-being of the individual' (O'Donovan 2000:22). It is the conversational community in which one's philosophy of life, including religion, is narratively shared for mutual growth and unity in love and peace. This notion is expanded on by Resane (2020:260), that the theology of dialogue is 'when partners share their religious faith and experiences in an atmosphere of peace, to seek to understand a partner's religious convictions'. In another place, Resane (2018) emphasises the following:

Dialogues often take the form of theological consultations, which highlight differences and seek ways of coming closer together through new understandings, reinterpretation or correction of misunderstandings, and healing of divisions. (p. 3)

It is clear then that when ideologues dialogue, harmony, peace and stability flourish in diverse societies such as South Africa. South African cultures and religions need to converge, confer, convene, and consult with each other in order to make democracy an experiential reality. This is how community is built, since 'all people are by nature social and tend to live in communities' (Nkadimeng 2020:109). Multi-cultural and multi-religious societies are expected to live and work towards being structurally dialogical. This paves the way for humanity to rediscover itself; and it is the beginning of an eschatological human journey towards fulfilment. These dialogues expand platforms for humans to find expression in and enhance their vertical and horizontal relationships their relationships with God and others.

Theology is both preventative and interventional. It speaks into situations of conflict in order to bring sanity, stability and the shalom of God. And it plunges itself into the midst of crises, sufferings, and violence in order to bring healing and restoration. In agreement with Pobee (in Kroesbergen 2015:18), theology's role is to mediate between cosmological and eschatological realities. This mediation must be dialogical, for 'even the eschatological must be in dialogue with the cosmological, the present worldly realities' (Pobee in Kroesbergen 2015:18). After all, 'theology must be relational and communicative' (Moltmann 2019:124). Silent theology amidst a crisis is not God-honouring, Christexalting or human-respecting. Relationships are forged and enhanced by centring theology in cultural diversity. Resane (2018:2) cries for the truth that theology 'is a moseka phofu [a herald] who is not afraid to lose voice to defend what rightly belongs to her'. In this case, Resane refers to the community or the church as what belongs to, and where theology exerts its voice. Theology and culture are integrally related, but theology remains a public discipline, which is 'concerned with human relationships, predicaments, and obligations involved in human action and accountability concerning 
God, humanity, and the world' (Chung 2017:160). Failure to play this role, leads to cultural demise where godlessness prevails, and human dignity is exposed to emotional onslaught.

\section{Theology and culture: Dialogical partners}

Theology and culture are supposed to be comrades in arms. They are in many ways complementary to social identity and stability. Culture plays a leading role in articulating the Christian faith. 'As source of theology, culture is the incorporating element that correlates the religious substance and the cultural expressions of a given society' (Elenga, in Brennan 2010:36). It becomes the medium through which theology finds expression. Theology expresses itself through culture, and culture finds its fulfilment in theology. 'Culture becomes a crucial and critical tool for expressing theological ideas and concepts if theology would be meaningful and transformational, and missional in nature' (NkansahObrempong 2007:2). Life, faith, and ecclesiastical activities in societies take place in specific cultural contexts. There is no theology beyond, beneath or beside cultural and contextual references. There is a biblical injunction that during the exodus, the shekinah, the pillar of fire was not only visible to the Hebrews, but also to the Egyptians.

During the last watch of the night, the LORD looked down from the pillar of fire and cloud at the Egyptian army and threw it into confusion. He made the wheels of their chariots come off so that they had difficulty driving. And the Egyptians said, 'Let's get away from the Israelites! The LORD is fighting for them against Egypt' (Ex 14:24-25).

Christ taught that it is impossible to influence the world from a distance. Participation, insulation, immersion and dialogue rather than isolation, bring appreciation, enlightenment, understanding, and respect for each other. The Sermon on the Mount is clear, we cannot understand each other until we become salt and light (insulated and beaming):

\footnotetext{
'You are the salt of the earth. But if the salt loses its saltiness, how can it be made salty again? It is no longer good for anything, except to be thrown out and trampled underfoot'. You are the light of the world. A town built on a hill cannot be hidden. Neither do people light a lamp and put it under a bowl. Instead they put it on its stand, and it gives light to everyone in the house. In the same way, let your light shine before others, that they may see your good deeds and glorify your Father in heaven. (Mt 5:13-16)
}

The apostolic church of the Roman era was always confronted with situations in which the Christian and the pagan worlds came closer to each other. Think of the slaves and the masters in the same household, worshipping together and doing a life of discipleship together. Non-believers and Christians coexisted in the same community and neighbourhood. Their habitats were the real oikos [the household]. No wonder that the Christian community of the time called itself a 'household of God'. Lampe (2003) is correct that:
In this 'house' some integration took place, as the book of Hermas shows. Tatian emphasizes that at Christian gatherings all take part equally without regard to status - from the old woman to the young boy who has no beard yet (Or. 32.3, 1; 33.1). (pp. 98-99)

Cultural segregation and division do not synchronise with Christian faith principles, as far as from the enactment of the church in the early century. The church has always been known for social mix where ethnic, tribal or racial stratum was never a consideration for participation. Culture was never used as an instrument of division when coming to worship. In recalling the church father Justin Lampe (2003) continues to highlight the fact that:

In the Christian community people gather at one table who, before their baptism, because of their differing ethnic customs, would not have had fellowship around the hearth together. The integration achieved by Christianity is here nicely expressed. (p. 102)

There are many African cultural traits that symbiotically and harmoniously express some theological sensibilities and constructs. In other words, culture provides the tools necessary for constructing theological realities. Culture is 'theology's embedding context' (Grenz \& Franke 2001:130). For instance, communion ecclesiology, as theological epistemology, can be expressed as African ubuntu/botho in which togetherness is the common identity and part of the composition. Around this ubuntu/botho, there are also theological expressions of the ecclesia, koinonia, diakonia, neighbourliness, perichoresis, Christian love, et cetera. The indisputable fact is that 'ubuntu brings Christianity and African culture closer. It is a powerful motif that can contribute enormously in transforming Christianity and vice versa' (Resane 2017:112). Gaps that developed during the colonial and apartheid eras are to be addressed in humility and love, through theo-cultural dialogue. Failure to enter into this dialogue exacerbates separatism, xenophobia, and violence (McLennan 2016:128). Dialogical partners, in this case culture and theology, should come closer to each other with the attitude of openness, transparency, and teachability. O'Donovan's (2000) advice should be noted:

No culture is best. No culture is right in everything. There are things in every culture which must be rejected by the sincere Christian because they are not pleasing to God. There are also beneficial things which can be learned from every culture. (p. 15)

That is why there is no such a thing as a culture-free theology. This notion is both ill-founded and theologically or biblically unwarranted. Theology can never be practical outside of culture. Its theology-ness finds a genuine expression and identity within culture. Culture offers theology a space to exert and express its essence, identity, and message. Theology in symbiosis with culture becomes omnibus aut nihil [all or nothing].

\section{Conclusion}

When different cultural groups occupy the same territory, conflicts and collisions are inevitable, and violence as a tool 
of solution becomes a praxis. However, as argued by Bushman in Petkošsek \& Žalec (2019):

... with the intensification of processes, we all are residents of a multi-cultural, multi-religious and multinational community in which there is no common value system, a single ideology and a unified education. (p. 145)

Culture's intrinsic nature is dialogical just as much as theology is dialogical. The legacy of separateness, segregation, exclusion and isolation, left by colonialism and apartheid, created some difficulties for Christian communal enjoyment. All the actions, theologies, and value systems that result in alienation from God and from neighbour (Cannon in Dibeela, Lenka-Bula \& Vellem 2014:180), in any ideological form, is evil and therefore needs to be rejected with contempt. Culture and religion were used to divide, instead of as tools for inclusion and embrace. This historical misnomer should become an open opportunity for theological intervention through dialogical processes. The multi-cultural and multi-religious democratic South Africa continues to need theological conversation towards harmony and peace. Theologians are the co-participants with people around them in an ongoing conversation about what it means to be human, and this conversation occurs within a specific cultural context' (Grenz 2000:47). Dialogue between culture and theology is an inevitable necessity. In fact, it has become a necessary trouble. Regardless of discomfort, disagreements, disjointedness, conflicts or convergences, this dialogue is an ongoing demand for harmonious coexistence, in which socio-political divisions made some indelible marks that imprint subliminal hatred and prejudice. 'Theology and culture must then be viewed as entertaining a permanent dialogue for the search of meanings and values' (Elenga 2010:38). As dialogical partners, their efforts and deliberations defuse subliminal and underlying tensions in multi-cultural and multi-religious societies such as South Africa. These attempts result into harmonious multi-cultural and multi-religious communities. Theological dialogue is indeed, 'an essential prerequisite for a common life and a creation of moral bonds' (Strahovnik in Petkošsek \& Žalec 2019:74) in a multi-cultural and multi-religious South Africa. It should be regarded as a divine gift to be enjoyed, rather than a menace to be abhorred. Cultural diversity is to be nurtured and celebrated. The freedom upon which it is based, should be 'particularly precious and must be preserved and extended to those who have been excluded from full participation in a free society' (Thiemann 1991:47).

To be a democratic and a unitary state composed of diverse cultures and religions, does not disqualify nationhood, instead it enhances it, and to a certain degree promotes patriotism and national identity. Chung (2017) captures it well:

Diversity, difference, and plurality in religious cultural worldviews are important factors in shaping and characterizing our understanding of morality and religious ethics in a comparative manner for public theology. (p. 160)
Multi-culturality and multi-religiosity is dialogically achievable through the theological conviction that humanity in diversity is created in the image of God; and that its heterogeneity contributes towards harmonious coexistence.

\section{Acknowledgements Competing interests}

The author declares that he has no financial or personal relationships that may have inappropriately influenced him in writing this article.

\section{Author's contributions}

By reviewing literature on Old Testament studies, systematic theology, history, and women's literature, this Old Testament narrative has been discovered to possess some potential to teach on women's rights to possess and utilise land, gender equity, the empowerment of women and women's capacity to contribute to economic growth.

\section{Ethical considerations}

This article followed all ethical standards for research without direct contact with human or animal subjects.

\section{Funding information}

This research received no specific grant from any funding agency in the public, commercial, or not-for-profit sectors.

\section{Data availability}

Data sharing is not applicable to this article as no new data were created or analysed in this study.

\section{Disclaimer}

The views and opinions expressed in this article are those of the author and do not necessarily reflect the official policy or position of any affiliated agency of the author.

\section{References}

Barnes, A., 1979, Notes on the Old \& New Testaments: An explanatory and practical commentary, Baker Book House, Grand Rapids, MI.

Bushman, I., 2019, 'Intercultural dialogue in the Ukrainian society' in R. Petkošsek \& B. Žalec (eds.), Religion as a factor of intercultural dialogue, pp. 143-148, Lit Verlag $\mathrm{GmbH}$, Zurich.

Butkus, R.A. \& Kolmes, S.A., 2011, Environmental science and theology in dialogue, Orbis Books, Maryknoll: CT.

Cannon, K.G., 2014, 'Lessons of liberation in the struggle for freedom', in P. Dibeela, P. Lenka-Bula \& V. Vellem (eds.), Prophet from the south, pp. 171-184, Sun Media, Stellenbosch.

Chicago Tribune, 1990, 'South African blacks forced to deal with issue of tribalism' (NEXIS), Chicago Tribune, 10 September 1990 North Sports Final Edition, viewed 13t January 2021, from https://www.refworld.org/docid/3ae6aaeb30.html

Chung, P.S., 2017, Postcolonial public theology: Faith, scientific rationality, and prophetic dialogue, James Clarke, Cambridge.

Clooney, F.X., 2010, Comparative theology: Deep learning across religious borders, Wiley-Blackwell, Malden.

Cochrane, J.R., 2000, 'Religious pluralism in post-colonial public life', Journal of Church and State 42(3), 443-465. https://doi.org/10.1093/jcs/42.3.443

Coetzee, P.H. \& Roux, A.P.J., 2000, 'Particularity in morality and its relation to community', in P.H. Coetzee \& A.P.J Roux (eds.), Philosophy from Africa: A text with readings, pp. 275-291, Oxford University Press, Oxford. 
Crafford, D., 1996, 'The theology of religions', in P. Meiring (ed.), A world of religions (A South African perspective), pp. 220-244, Kagiso Publishers, Pretoria.

De Gruchy, J.W., 1993, 'Christian witness and the transformation of culture in a society in transition', in H. Regan \& A.J. Torrance (eds.), Christ and context, pp. 131-152, Clark, Edinburgh.

Delotavo, A.J., 2012, Contemporary evangelicalism and the restoration of the prototypal church, Fresh Ideas Books, viewed 17 January 2021, from www. delotavo.com

Dobšová, J., 2009, 'Calvinism in the context of the Afrikaner nationalist ideology', Asian and African Studies 78(2), 305-323.

Dubow, S., 1992, 'Afrikaner nationalism, apartheid and the conceptualization of "race", The Journal of African History 33(2), 209-237. https://doi.org/10.1017/ S0021853700032217

Elenga, (SJ) Y.C., 2010, 'Theology and culture(s) in higher education: An African perspective in a global context', in F. Brennan (SJ) (ed.), Shaping the future:
Networking Jesuit higher education for a globalizing world, pp. 36-38, Report of Networking Jesuit higher education for a globalizing world, pp. 36-38, Report of
the Mexico Conference, April 2010, Association of Jesuit Colleges \& Universities, the Mexico Conf Orleans, LA

Gallagher, M.P., 2004, 'University and culture: Towards a retrieval of humanism', Gregorianum 85(1), 149-171.

Gibson, J.L. \& Gouws, A., 2003, Overcoming intolerance in South Africa: Experiments in democratic persuasion, Cambridge University Press, Cambridge.

Government Communication and Information System (GCIS), 2012, Pocket guide to South Africa 2011/2012 South Africa's people, viewed n.d., from https://www. gcis.gov.za/sites/www.gcis.gov.za/files/docs/resourcecentre/pocketguide/004_ saspeople.pdf

Grenz, S.J., 2000, 'Culture and spirit: The role of cultural context in theological reflection', The Asbury Theological Journal 55(2), 37-51.

Grenz, S.J. \& Franke, J.R., 2001, Beyond foundationalism: Shaping theology in a postmodern context, Westminster John Knox Press, Louisville, KY

Jamnik, A., 2019, 'Religious and cultural tensions and their overcoming in the time of globalisation', in R. Petkošsek \& B. Žalec (eds.), Religion as a factor of intercultural dialogue, pp. 77-91, Lit Verlag GmbH, Zurich.

Kato, B.H., 1975, Theological pitfalls in Africa, Evangel Publishing House, Kisumu.

Kovács, G., 2019, 'The problem of the dialogue between civilisations and their attitudes to religious faith - Oswald Spengler and his cultural morphology at the border of the long 19th century', in R. Petkošsek \& B. Žalec (eds.), Religion as a border of the long 19th century', in R. Petkošsek \& B. Zalec (eds.), Relig
factor of intercultural dialogue, pp. 119-126, Lit Verlag GmbH, Zurich.

Kusmierz, K. \& Cochrane, J.R., 2013, 'Public church and public theology in South Africa's political transformation', in C. Lienemann-Perrin \& J.R. Cochrane (eds.), The church and the public sphere in societies in transition, pp. 49-90, Cluster The church and the public
Publications, Dorpspruit.

Lampe, P., 2003, From Paul to Valentinus: Christians at Rome in the first two centuries, Clark International, London.

Le Roux, C., 2011, 'The ethnic conflict in Mangaung at Bloemfontein in 1957', Southern Journal for Contemporary History 36(1), 20-39.

Lubbe, G., 2002, 'Religio-political changes in South Africa', in D. Kritzinger (ed.), No quick fixes: The challenge of mission in a changing South Africa, pp. 61-69, University of Pretoria, Pretoria.

Manzo, K.A., 1996, Creating boundaries: The politics of race and nation, Lynne Reiner Publishers.

Marshall, I.H., 1998, The Acts of the Apostles: An introduction and commentary, Leicester, InterVarsity, London.

Mathwig, F. \& Lienemann, W., 2013, 'Churches as civil society actors in current political transformation processes: Reflections on a typology', in C. LienemannPerrin \& J.R. Cochrane (eds.), The church and the public sphere in societies in Perrin \& J.R. Cochrane (eds.), The church and the pubstion, pp. 1-48, Cluster Publications, Dorpspruit.
transita

McGavran, D., 1972, Eve of the storm, Word Books, Waco, TX.

McLennan, S., 2016, Christ for unitarian universalists: A new dialogue with traditional Christianity, Skinner House Books, Boston, MA.

Meylahn, J., 2012, Church emerging from the cracks: The Church IN, but not OF the world, Sun Press, Bloemfontein.
Moltmann, J., 2000, Experiences in theology: Ways and forms of Christian theology, Fortress Press, Minneapolis, MN.

Moltmann, J., 2003, The experiment hope, Wipf \& Stock, Eugene.

Moltmann, J., 2019, The spirit of hope: Theology for a world in peril, John Knox Press, Louisville, KY.

Nkadimeng, T., 2020, Growing in our understanding of God: Theological perspectives, Bibliotos Publishers, Pietermaritzburg.

Nkansah-Obrempong, J., 2007, 'Theology and culture': A paper delivered at a UBS Consultation in Nairobi, Kenya on May 9, 2007 at the KCB Management Training Center, Karen.

O'Donovan, W., 1996, Biblical Christianity in African perspective, 2nd edn., Paternoster Press, Carlisle.

O'Donovan, W., 2000, Biblical Christianity in modern Africa, Paternoster Press, Carlisle.

Orobator, A.E., 2008, Theology brewed in an African pot, Orbis Books, New York, NY.

Osredkar, M.J., 2019, 'Dialogue between an idea and reality', in R. Petkošsek \& B. Žalec (eds.), Religion as a factor of intercultural dialogue, pp. 135-142, Lit Verlag GmbH, Zurich.

Pobee, J.S., 2015, 'Christian identity in a globalised world', in H. Kroesbergen (ed.), Christian identity and justice in a globalised world from a Southern African perspective, pp. 14-30, Christian Literature Fund, Wellington.

Prijatelj, E., 2019, 'Digital culture and religion in intercultural dialogue', in R. Petkošsek \& B. Žalec (eds.), Religion as a factor of intercultural dialogue, pp. 165-171, Lit Verlag $\mathrm{GmbH}$, Zurich.

Ratzinger, J., 2004, Introduction to Christianity, Communio Books/Ignatius Press, San Francisco, CA.

Resane, K.T., 2017, Communion ecclesiology in racially polarised South Africa, SUN MeDIA, Bloemfontein.

Resane, K.T., 2018, 'Transparent theological dialogue - Moseka Phofu Ya Gaabo Ga a Tshabe Go Swa Lentswe' (A Setswana proverb), Religions 9(2), 54. https://doi. org/10.3390/rel9020054

Resane, K.T., 2020, South African Christian experiences from colonialism to democracy, Sun Media, Bloemfontein.

Richie, T., 2011, Speaking by the spirit: A Pentecostal model for interreligious dialogue, Emeth Press, viewed 22 February 2021, from www.emethpress.com

Robertson, A.T., 1931, Word pictures in the New Testament, vol. III: The Acts of the Apostles, Broadman, Nashville, TN.

Sauter, G., 2003, Gateways to dogmatics: Reasoning theologically for the life of the church, Eerdmans, Grand Rapids, MI.

Slack, J., 2010, 'Practices in orality: The existence, identification, and engagement of a people's worldview', in S. Chiang et al. (eds.) Orality breakouts: Using heart language to transform hearts, pp. 73-80, International Orality Network/Lausanne language to transform hearts, pp. 73-80, Intern
Congress on World Evangelisation, Hong Kong.

Slatinek, S., 2019, 'Problems of marital dialogue in disputed litigations, and solutions offered by Amoris Laetitia', in R. Petkošsek \& B. Žalec (eds.), Religion as a factor of intercultural dialogue, pp. 181-190, Lit Verlag GmbH, Zurich.

South African History Online, 2020[2016], People and culture of South Africa, viewed n.d., from https://www.sahistory.org.za/article/people-and-culture-south-africa

Strahovnik, V., 2019, 'Overcoming the delusion of neutrality of public discourse', in R. Petkošsek \& B. Žalec (eds.), Religion as a factor of intercultural dialogue, pp. 69-76, Lit Verlag GmbH, Zurich.

Thiemann, R.F., 1991, Constructing a public theology: The church in a pluralistic culture, John Knox Press, Louisville, KY.

Thomas, D., 2002, Christ divided: Liberalism, ecumenism and race in South Africa, UNISA, Pretoria.

Valji, N., 2003, 'Creating the nation: The rise of violent xenophobia in the New South Africa', unpublished Masters' thesis, York University, Toronto.

Volf, M., 1996, Exclusion and embrace: A theological exploration of identity, otherness, and reconciliation, Abingdon Press, Nashville, TN.

Wagner, C.P., 1994, Blazing the way: A new look at Acts - Sharing God's power throughout the world, Book 3 Acts 15-28, Regal Books, Ventura. 